\title{
Evaluation of latex agglutination test and oxacillin resistant screening agar base (ORSAB) medium for the detection of oxacillin resistant coagulase negative Staphylococci (ORCoNS) (Preliminary study)
}

\author{
Sjoekoer M Dzen, Sanarto Santoso, Roekistiningsih, Dewi Santosaningsih
}

\begin{abstract}
Abstrak
Stafilokokus koagulase negatif (SCoN) adalah penyebab infeksi nosokomial yang dianggap penting, terutama pada neonatus dan pasien yang menggunakan alat protesis yang melekat di tubuh. Angka resistensi SCoN pada oksasilin sedang meningkat. Karena itu, deteksi cepat dan akurat resistensi terhadap oksasilin menjadi sangat penting untuk menentukan terapi antimikroba yang tepat. Penelitian ini bertujuan untuk membuktikan bahwa tes aglutinasi lateks dan skrining resistensi terhadap oksasilin pada medium berbasis agar (ORSAB) dapat digunakan untuk deteksi cepat SCoN yang resisten terhadap oksasilin (SCoNRO). Pada penelitian ini tes aglutinasi lateks dan medium ORSAB dibandingkan dengan cara konvensional pada 30 isolat klinik SCoN untuk mendeteksi SCoNRO. Tes Mc Nemar digunakan untuk menganalisis data. Hasil analisis menunjukkan bahwa tidak ada perbedaan bermakna (P >0,05) dalam hal deteksi SCoNRO antara tes aglutinasi lateks dan medium ORSAB dibandingkan dengan cara konvensional. Karena itu, dapat disimpulkan bahwa tes aglutinasi lateks dan medium ORSAB dapat digunakan untuk deteksi cepat SCoNRO. (Med J Indones 2007; 16:228-32)
\end{abstract}

\begin{abstract}
Coagulase negative Staphylococci (CoNS) are recognized as an important cause of nosocomial infection, especially in neonates and patients with indwelling prosthetic devices. The CoNS resistance rate to oxacillin has been increasing. Therefore, rapid and accurate detection of oxacillin resistance is essential in order to determine the most appropriate antimicrobial therapy. This study aimed to prove that latex agglutination test and oxacillin resistant screening agar base (ORSAB) medium can be used for rapid detection of oxacillin resistant CoNS (ORCoNS). Latex agglutination test and ORSAB medium compared with the conventional method was conducted in this study toward 30 clinical isolates of CoNS for the detection of ORCoNS. Mc Nemar test was used to analyze the data. The study result revealed that there was no significant difference $(P>0.05)$ in terms of ORCoNS detection between the latex agglutination test and ORSAB medium on the one hand, and the conventional method on the other. It is concluded that latex agglutination test and ORSAB medium can be used for rapid detection of ORCoNS. (Med J Indones 2007; 16:228-32)
\end{abstract}

Keywords: nosocomial infection, rapid detection, mecA gene

Coagulase negative Staphylococci (CoNS) are recognized as an important cause of nosocomial infection, especially in the form of bacteremia at neonates and immunocompromised patients or those with indwelling prosthetic devices. Pfaller (1998) stated in Iowa, that CoNS was the third cause of bacteremia after Staphylococcus aureus and Escherichia coli. ${ }^{1,2,3}$ The European prevalence of infection in intensive care (EPIC) study in Europe revealed that in patients using an intravenous catheter,

Microbiology Laboratory, Faculty of Medicine, Brawijaya University/Dr. Saiful Anwar General Hospital, Malang, Indonesia the coagulase negative Staphylococcus infection prevalence was $44.9 \%$ at the intensive care unit. The mortality rate due to this bacterial infection ranges between $18.5 \%$ and $57 \%{ }^{4}$ The study by Sjoekoer et al (2005) revealed that at a two period study, namely 2000-2001 and 2004-2005, CoNS prevalence was the highest among the bacteria identified in positive blood cultures of the patients hospitalized at the Dr. Saiful Anwar general hospital, Malang. ${ }^{5}$

Coagulase negative staphylococci (CoNS) are a common cause of bloodstream infection, and the majority of isolates are resistant to beta-lactam antibiotics. The mechanism of oxacillin resistance in CoNS such as 
Staphylococcus aureus is due to the production of an additional non native penicillin-binding-protein (PBP), PBP2a. The PBP2a has a low affinity for beta lactam antibiotics and is encoded by the mecA gene. ${ }^{6}$

The detection of oxacillin resistance in CoNS is complex and time consuming because of the heterogenous nature of mecA gene expression. Furthermore, in some species of CoNS, the differentiation between mecA-negative and mecA-positive strains may not be possible by susceptibility methods. Therefore, alternative methods for rapid and accurate detection of the oxacillin resistant strains are desirable. The present study aimed to evaluate the possibility of the use of latex agglutination test and oxacillin resistant screening agar base (ORSAB) medium for rapid detection of ORCoNS, by comparing them to the conventional method.

\section{METHODS}

The samples comprised of 30 CoNS bacterial clinical isolates, which were isolated from pus (15), sputum (9), blood (2), vaginal swab (2), semen (1), and cerebrospinal fluid (1) specimens of Dr. Saiful Anwar general hospital patients, all of which were sent to the Microbiology Laboratory of the Faculty of Medicine, Brawijaya University/Dr. Saiful Anwar general hospital.

\section{CoNS detection}

Direct examination by Gram stain was done to clinical specimens sent to the Microbiology Laboratory of the Faculty of Medicine, Brawijaya University/ Dr. Saiful Anwar general hospital. If Gram positive cocci were present, culturing of the clinical specimens was done in blood agar medium at $37^{\circ} \mathrm{C}$ for 18 to 24 hours followed by Gram stain. Detection of coagulase negative Staphylococci were done by catalase and coagulase.

\section{ORCoNS detection by conventional method}

Conventional CoNS oxacillin-sensitivity test was done by disc diffusion method according to NCCLS 2001.

\section{ORCoNS detection by latex agglutination test (Biomerieux)}

The CoNS suspension (Mc Farland 1) was inoculated in the Mueller Hinton Agar medium. Then oxacilliln $\operatorname{disc}(1 \mu \mathrm{g} / \mathrm{ml})$ was put on the inoculum. Incubation at $37^{\circ} \mathrm{C}$ was provided for 18 to 24 hours. Then a 3-5 $\mu 1$ CoNS suspension with 4 drops of the extraction reagent 1 was made in the micro-centrifugal tube. The bacterial suspension was then heated in boiling water for 3 minutes, after which it was cooled at room temperature. Then 1 drop of the extraction reagent 2 was added and centrifuged at 3,000 rpm for 5 minutes. Supernatan was used for the latex agglutination test. Then $50 \mu 1$ Supernatan was suspended in 1 drop of latex test reagent and shaken for 3 minutes and observed for possible agglutination; PBP2' was regarded positive if the latex test showed agglutination and the control was not (negative).

\section{ORCoNS detection by ORSAB medium (Oxoid)}

The separate CoNS bacteria colony obtained from method 1 was inoculated in the ORSAB medium. After incubation at $37^{\circ} \mathrm{C}$ for $18-24$ hours we observed the plate. It was positive if the medium color around the bacteria colony resistant to oxacillin changed from clear to blue.

\section{Statistical Analysis}

The results of latex agglutination test and ORSAB medium were compared to the result of conventional method by McNemar test using SPSS 10.0 software.

\section{RESULTS}

ORCoNS detection of 30 CoNS clinical isolates by conventional method showed that there were 3 isolates resistant and 27 sensitive to oxacillin. The same result was yielded by latex agglutination test. The three isolates were from sputum, pus and cerebrospinal fluid. The ORCoNS detection by ORSAB medium, however, yielded 8 resistant and 22 sensitive to oxacillin (Table 1).

McNemar test using SPSS 10.0 software showed that there were no significant differences between the result of latex agglutination test or ORSAB medium on the one hand, and conventional method on the other, in the detection of ORCoNS bacteria $(P>0.05)$ (Tables 2 , and 3). Table 4 shows the comparison between latex agglutination test and ORSAB medium. 
Table 1. ORCoNS detection using latex agglutination test, ORSAB medium and conventional method.

\begin{tabular}{|c|c|c|c|c|}
\hline No. of specimen & Isolate origin & $\begin{array}{c}\text { Latex agglutination } \\
\text { test } \\
(+/-) \\
\end{array}$ & $\begin{array}{l}\text { ORSAB medium } \\
(+/-)\end{array}$ & $\begin{array}{c}\text { Conventional method } \\
\text { (S/R) }\end{array}$ \\
\hline 461 & pus & - & - & $S$ \\
\hline 438 & sputum & - & + & S \\
\hline 1968 & sputum & - & - & S \\
\hline 2062 & sputum & + & + & $\mathrm{R}$ \\
\hline 2097 & semen & - & - & $S$ \\
\hline 586 & pus & - & - & S \\
\hline 1721 & blood & - & - & S \\
\hline 679 & pus & + & - & $\mathrm{R}$ \\
\hline 475 & sputum & - & - & S \\
\hline 1957 & pus & - & + & S \\
\hline 1876 & pus & - & - & S \\
\hline 1866 & pus & - & - & S \\
\hline 2116 & pus & - & - & S \\
\hline 478 & pus & - & - & S \\
\hline 1728 & blood & - & + & S \\
\hline 1863 & sputum & - & - & $\mathrm{S}$ \\
\hline 1575 & pus & - & - & $S$ \\
\hline 2045 & cerebrospinal fluid & + & + & $\mathrm{R}$ \\
\hline 3226 & sputum & - & - & S \\
\hline 354 & pus & - & - & S \\
\hline 350 & pus & - & - & $\mathrm{S}$ \\
\hline 2865 & pus & - & - & S \\
\hline 3225 & sputum & - & - & $S$ \\
\hline 2788 & sputum & - & - & S \\
\hline 3028 & pus & - & + & S \\
\hline 2829 & pus & - & + & S \\
\hline 302 & sputum & - & - & $S$ \\
\hline 313 & vaginal swab & - & + & S \\
\hline 3077 & vaginal swab & - & - & S \\
\hline 3221 & pus & - & - & $\mathrm{S}$ \\
\hline
\end{tabular}

Note: $\mathrm{S}=$ sensitive; $\mathrm{R}=$ resistant

Table 2. Comparison of latex agglutination test and conventional method.

\begin{tabular}{cccc}
\hline \multirow{2}{*}{ Conventional method } & \multicolumn{2}{c}{ Latex agglutination test } & \multirow{2}{*}{ total } \\
\cline { 2 - 4 } & positive & negative & 27 \\
Sensitive & 0 & 27 & 3 \\
Resistant & 3 & 0 & 30 \\
\hline total & 3 & 27 & \\
\hline
\end{tabular}

Table 3. Comparison of ORSAB medium and conventional method.

\begin{tabular}{ccccc}
\hline \multirow{2}{*}{ Conventional method } & \multicolumn{2}{c}{ ORSAB medium } & \multicolumn{2}{c}{ total } \\
\cline { 2 - 5 } Sensitive & positive & negative & 21 & 27 \\
Resistant & 6 & 1 & 3 \\
\hline total & 2 & 22 & 30 \\
\hline
\end{tabular}

Table 4. Comparison of latex agglutination test and ORSAB medium.

\begin{tabular}{cccc}
\hline \multirow{2}{*}{ Latex agglutination test } & \multicolumn{2}{c}{ ORSAB medium } & total \\
\cline { 2 - 4 } positive & positive & negative & 3 \\
negative & 2 & 1 & 21 \\
\hline total & 6 & 22 & 30 \\
\hline
\end{tabular}




\section{DISCUSSION}

Coagulase negative Staphylococci consist of several species, such as Staphylococcus epidermidis, Staphylococcus haemolyticus, Staphylococcus hominis, and Staphylococcus warneri. Due to the limitation of facilities, no further detection was made in this study. However, Giusti (1999) stated that Staphylococcus epidermidis is the most predominant species isolated. ${ }^{2}$ This was confirmed by Louie (2001) stating that from 200 CoNS isolates from blood, cerebrospinal fluid, urine, and from other sterile places in the body, 108 Staphylococcus epidermis isolates (54\%) were identified. ${ }^{7}$

Coagulase negative Staphylococci are bacteria that cause nosocomial infection, and mostly are resistant to beta-lactam antibiotics due to the production of another type of PBP (penicillin-binding-protein) namely PBP2a. This protein has low affinity to beta lactam antibiotics and encoded by $m e c A$ gene. ${ }^{7} \mathrm{MecA}$ gene is responsible to the bacterial resistance against penicillinaseresistant penicilllins such as dicloxacillin, methicillin, nafcillin and oxacillin. ${ }^{8}$ In this present study, therefore, CoNS which were resistant to methicillin (Methicilin resistant CoNS), were considered resistant to oxacillin as well and are referred to as oxacillin resistant CoNS (ORCoNS).

Phenotypic detection of staphylococci is a complicated problem and time consuming. This problem is caused by the various expressions of the mecA gene by many staphylococci strains. In the various resistant types, the genetic composition at a given bacteria population may be the same, but only some bacteria have the ability to express the respective PBP2a gene to be detected. Therefore, the standard procedure needs modification to make it less complicated, and an alternative method for rapid and accurate detection of the CoNS strain resistant to oxacillin is necessary. ${ }^{7}$

In this study, latex agglutination test and ORSAB medium were used to find an alternative for rapid and accurate detection method of ORCoNS, with the conventional method, that is more time consuming, functioning as control. The latex agglutination test procedure included overnight induction stage of the $m e c A$ gene by placing the oxacillin disc at the inoculum. However, earlier research claimed that induction was not needed to detect Oxacillin resistant Staphylococcus aureus. The overnight induction slows down the emergence of oxacillin resistant strain. The delay due to culturing CoNS originating from blood and other sterile body fluids can be overcome. If
Gram positive cocci at the positive blood or sterile body fluid culture are supported by a negative coagulase test result, the oxacillin disc can be placed at the inoculum when inoculation is done at solid medium. If on the following day, there is a growth of staphylococci, the bacteria colony surrounding the oxacillin disc can be rapidly used for latex agglutination test. However, CoNS from other isolates cannot be treated alike. ${ }^{7}$ Therefore, an overnight induction process was done to the mecA gene for all isolates under investigation in this study.

This study showed that the conventional method and latex agglutination test gave the same result in ORCoNS detection, with $P>0.05$ by McNemar statistical test. Consequently, it can be stated that accurate and rapid detection of ORCoNS can be done by latex agglutination test. Hussain Z (2000) using 463 CoNS isolates showed that 251 isolates gave mecA positive by PCR, which were the same with latex agglutination test and conventional method used as control. The PCR method was used as a reference to evaluate a new method in antimicrobial sensitivity to staphylococci. Therefore, it was claimed that latex agglutination test could be used for accurate and rapid ORCoNS detection. $^{7}$

The present study also revealed that there was a slight difference between the conventional method and ORSAB medium in ORCoNS detection. However, there was no significant difference in statistical terms $(P>0.05)$ (Table 3). Moreover, ORCoNS detection using ORSAB medium was also used by Becker, et al (2002) who could identify $82 \%$ of the isolates as Staphylococcus haemolyticus (a CoNS species) which was resistant to oxacillin. Diederen et al (2005) said that only $1.6 \%$ of CoNS showed false positive result in ORSAB medium after 24-hour incubation; and that if the incubation was continued to 48 hours, the false positive result was increased to $6.0 \%$.

This study did not apply the measurements of sensitivity, specificity, positive predictive value, and negative predictive value due to the small number of samples.

However, those measurements need to be conducted using more samples; and it is suggested that the polymerase chain reaction (PCR) method is used as one of the comparisons.

In conclusion, latex agglutination test and ORSAB medium might be used for rapid detection of ORCoNS. 


\section{REFERENCES}

1. Pfaller MA, Jones RN, Doem GV, Kugler K, Group SP. Bacterial pathogens isolated from patients with bloodstream infections frequencies of occurrence and antimicrobial surveillance program (United States and Canada). Antimicrobial Agents and Chemotherapy. 1998;42(7):1762-70.

2. Giusti MD, Pacifico L, Tufi D, Panero A, Boccia A, Chiesa C. Phenotypic detection of nosocomial mecA positive coagulase negative Staphylococci from neonates. Journal of Antimicrobial Chemotherapy. 1999; 44 :351-8.

3. Graham JC, Murphy OM, Stewart D, Kearns AM, Galloway A, Freeman R. Comparison of PCR detection of mecA with methicillin and oxacillin disc susceptibility testing in coagulase-negative Staphylococci. Journal of Antimicrobial Chemotherapy. 2000;45:111-3.

4. Burnie JP, Naderi-Nasab M, Loudon KW, Mattews RC. An epidemiological study of blood culture isolates of coagulase - negative Staphylococci demonstrating hospitalacquired infection. J Clin Microbiol. 1997;37(7):1746-50.

5. Dzen SH, Sanarto S, Roekistiningsih, Santosaningsih D. Perbedaan pola resistensi Staphylococcus koagulase negative isolat darah terhadap antibiotika di RSU dr. Saiful Anwar tahun 2000 - 2001 dengan 2004 - 2005. Jurnal Kedokteran Brawijaya. 2005; 21(3):127-32.

6. Hussain Z, Stoakes L, Garrow S, Longo S, Fitzgerald V, Lannigan R. Rapid detection of mecA-positive and mecAnegative coagulase-negative Staphylococci by an antipenicillin binding protein 2 a slide latex agglutination test. J Clin Microbiol. 2000; 38(6):2051-4.

7. Louie I, Majuri-Goodfellow J, Louie M, Simor AE. Evaluation of a latex agglutination test (MRSA - screen) for detection of oxacillin resistance in coagulation-negative Staphylococci. J Clin Microbiol. 2001; 39(11):4149-51.

8. Tenover FC, Jones RN, Swenson JM, Zimmer B, McAllister S, Jorgensen JH. Method for improved detection of oxacillin resistance in coagulation-negative Staphylococci: Result of a multicenter study. J Clin Microbiol. 1999;37(12):4051-8.

9. Becker A, Fodter DH, Knicht E. Oxacillin resistance screening agar base for detection of methicillin - resistant Staphylococcus aureus. J Clin Microbiol. 2002;40(11): 4400-1.

10. Diederen B, van Duijn I, van Belkum A, Willemse P, van Keulen P, Kluytmans J. Performance of CHROMagar MRSA medium for detection of methicillin-resistant Staphylococcus aureus. J Clin Microbiol. 2005;43(4): 1925-7. 
